\title{
NOTE
}

\section{Hatching rate of the egg-carrying estuarine copepod Eurytemora affinis}

\author{
Christian Marc Andersen, Torkel Gissel Nielsen*
}

\begin{abstract}
National Environmental Research Institute, Department of Marine Ecology and Microbiology, Frederiksborgvej 399, PO Box 358, DK-4000 Roskilde, Denmark
\end{abstract}

\begin{abstract}
The egg-carrying copepod Eurytemora affinis is often a characteristic and dominant component in the carbon cycles of freshwater influenced marine ecosystems in the Northern Hemisphere. In egg-carrying copepods the specific egg production rate in the field can be calculated from the egg hatching rate at in situ temperatures, the egg/female ratio and the carbon content of the eggs and females. To determine the temperature dependent egg hatching time (HT) of 2 populations of $E$. affinis, hatching experiments were conducted at 6 different temperatures $(T)$. Hatching times ranged from 14.1 to $1.6 \mathrm{~d}$ at 5 and $22^{\circ} \mathrm{C}$, respectively. Results from the 2 populations were pooled and fitted to a power function: $\mathrm{HT}=187 T^{154}\left(\mathrm{r}^{2}=0.97 ; \mathrm{p}<0.001\right)$. There is a large range in the hatching times versus temperature reported in the literature, and our results reveal longer hatching times than previously reported. To overcome this pronounced variation in hatching times, we present a significant relationship $\left(\mathrm{r}^{2}=0.87 ; \mathrm{p}<0.001\right)$ based on all available data: $\mathrm{HT}=$ $36.8 T^{-104}$
\end{abstract}

KEY WORDS: Eurytemora affinis - Egg production - Hatching rate

Copepods are considered to be some of the most important grazers in pelagic ecosystems. A key species in freshwater influenced marine ecosystems is the eggcarrying calanoid copepod Eurytemora affinis. It is widely distributed in the Northern Hemisphere and often dominates copepod biomass in estuaries (Jeffries 1962, Heinle \& Flemer 1975), salt marshes, lagoons (Castonguay \& Fitzgerald 1990) and brackish lakes (Jeppesen et al. 1994, Irvine et al. 1995).

Eurytemora affinis is an omnivorous suspension feeder, capable of exploiting a large particle spectra. The diet may consist of algae, protozoa, bacteria, and detritus within the size range of 1 to $60 \mu \mathrm{m}$ (Heinle et al. 1977, Heerkloss 1979, Gyllenberg 1980, Barthel 1983, Boak \& Goulder 1983). Since small-sized parti-

·Addressee for correspondence.E-mail: tgn@dmu.dk cles and detritus are often found in high concentrations in estuaries, E. affinis potentially plays an important role in trophic dynamics, making these carbon sources available for higher trophic levels.

The consumption rate and production of copepod populations can be estimated from measurements of the weight-specific egg production rate and the standing stock (Kiørboe et al. 1985a, b). This method assumes equal weight-specific growth rates in all stages and a close correlation between ingestion and egg production (Kiørboe et al. 1985a, b, Berggreen et al. 1988 , Fryd et al. 1991). Egg production rates of free-spawning copepod species are determined by incubation of adult females under in situ conditions as described by Kiorboe et al. (1985a, b). However, this method cannot be implemented directly to egg-carrying copepods, such as Eurytemora, because the dense egg sacs makes it impossible to count eggs on live females. Instead the population-specific egg production rate (SEP, $d^{-1}$ ) in the field can be calculated from the egg hatching rate (HR, $\mathrm{d}^{-1}$ ) at in situ temperature, the ratio of eggs to females (eggs/o) and the carbon content of the egg (eggC) and females (oC) respectively.

$$
\mathrm{SEP}=(\text { eggs } / \text { }) \mathrm{HR}(\mathrm{eggC} / \mathrm{QC})
$$

Egg hatching rate can be calculated if the egg hatching time at the in situ temperature is known. Here we define hatching time as the time from extrusion of eggs into the egg sac until eggs have hatched. A comprehensive study of the literature revealed several previous studies dealing with embryonic development in $E$. affinis, but only 4 papers report data that can be interpreted as hatching times according to this definition (see Table 1). There is a pronounced variation in the hatching times reported, but it is not clear if the differences are due only to natural variation among populations or if they are also attributable to the variation in terms and methods used. 


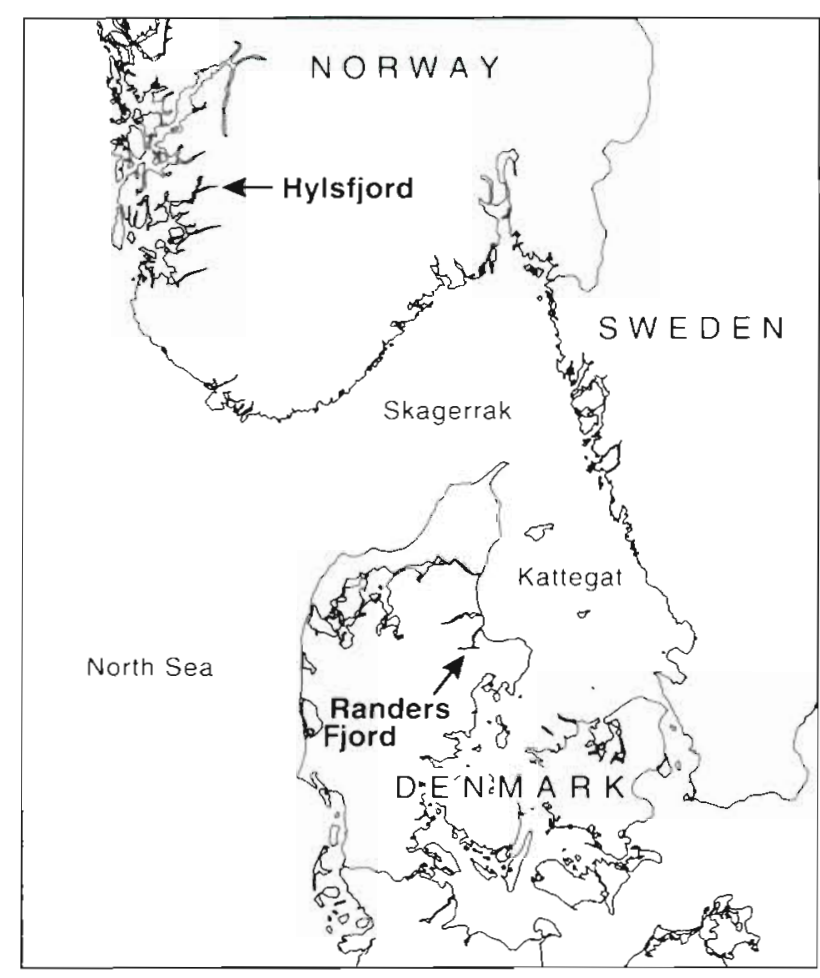

Fig. 1. Location of the study sites

The aim of this study was to determine the temperature dependent egg hatching rate of Eurytemora affinis by using the same method in 2 different populations. We compare our findings with earlier studies of egg development of $E$. affinis and also provide an overview of the different methods and terms used. Finally we establish a general equation relating hatching time and temperature based on all available data from the literature. This equation provides a simple method of estimating the productivity in the field of this abundant copepod species.

Materials and methods. Study sites: Sampling and experiments were carried out during 2 cruises in 1995. The Hylsfjord, situated on the southwestern coast of Norway (Fig. 1), was visited from 5 to 13 July with RV 'Hakon Mosby' (University of Bergen). The Hylsfjord is a deep fjord (max. depth $510 \mathrm{~m}$ ) separated from the ocean by a $110 \mathrm{~m}$ deep sill. It is strongly influenced by freshwater discharge from a hydroelectric power plant. A more detailed description of the fjord is given in Kaartvedt \& Svendsen (1995). Another cruise, to the Randers Fjord, Denmark, was carried out with RV 'Gunnar Thorson' (Danish National Environmental Protection Agency) from 5 to 9 September. Additional samplings in the Randers Fjord were carried out on 22 May 1996 from a small ship provided by Århus County. The Randers Fjord is a shallow estuary (max. depth $6 \mathrm{~m}$ ) which connects the Gudenå river with the
Kattegat (Fig. 1). For a more detailed description of the estuary see Nielsen et al. (1993).

Hatching experiments: Copepods were collected from surface waters by horizontal net hauls using a WP-2 net (mesh size $200 \mu \mathrm{m}$ ) with a large non-filtering cod-end. The samples were diluted in surface water and kept in a large insulated plastic container (100 l). Shortly after, subsamples were placed in small petri dishes and brought to the laboratory. Here females carrying egg sacs were sorted out with a pipette, under a dissecting microscope, and transferred to $600 \mathrm{ml}$ polycarbonate bottles ( 3 to 6 o bottle ${ }^{-1}$ ) containing $45 \mu \mathrm{m}$ screened surface water. Care was taken to maintain the animals at in situ temperature, because heating would have influenced the egg hatching time. Acclimation corresponding to experimental temperatures was not carried out prior to experiments.

The hatching experiments were conducted in temperature controlled incubators at 6 different temperatures: 5 and $22^{\circ} \mathrm{C}$ (Randers Fjord, September 1995), 12 and $18^{\circ} \mathrm{C}$ (Hylsfjord), and 8 and $15^{\circ} \mathrm{C}$ (Randers Fjord, May 1996). At the beginning of each experiment $\left(t_{0}\right)$ and every 6,12 or $24 \mathrm{~h}$, dependent on incubation temperature, the contents of each of 3 replicate bottles from each experiment were concentrated on $45 \mu \mathrm{m}$ sieves and rinsed into small petri dishes, where they were checked to see if females were alive and healthy. Animals were preserved by adding a few drops of Lugol's solution to each petri dish, and eggs and nauplii were counted under a dissecting microscope $(\times 25)$.

To avoid the source of error due to the possible production of new eggs during experiments, the hatching percentage was calculated in relation to the initial number of eggs $\mathrm{Q}^{-1}$ by:

\section{Hatching percentage $=$}

[no. of nauplii /(no. of $q \cdot$ initial no. of eggs $\left.\left.q^{-1}\right)\right] \cdot 100$

The initial number of eggs $q^{-1}$ was calculated as the mean number of eggs $Q^{-1}$ at $t_{0}$ in all experiments $(6 \times 3=$ 18 bottles). The hatching rate (HR) was calculated in each of the 6 experiment, from the slope of the linear regression of hatching percentage versus time. Hatching time (HT). defined as the time required to reach $100 \%$ of hatching, was also calculated from the linear regression.

There is some confusion in the literature concerning the systematics of the genus Eurytemora. According to Busch \& Brenning (1992), the species E. hirundoides should be regarded only as a variety of the very variable species $E$. affinis. Consequently no distinction between the 2 species is made in the following, and only the name $E$. affinis is used.

Results. Both fjords were characterised by a thin plume of outgoing low salinity water separated by a steep pycnocline from more saline bottom water (see 
Table 1. Eurytemora. Previous studies on embryonic development time

\begin{tabular}{|c|c|c|c|c|c|c|c|c|}
\hline Expt & $\begin{array}{l}\text { Temp. } \\
\text { range } \\
\left({ }^{\circ} \mathrm{C}\right)\end{array}$ & Equation & & $\begin{array}{l}\text { Data on } \\
\text { hatching } \\
\text { time }\end{array}$ & Term used & Study site & Source & $\begin{array}{l}\text { Symbol } \\
\text { used in } \\
\text { Figs. } 4 \& 5\end{array}$ \\
\hline Lab & $7-18$ & $D_{\mathrm{e}}=34.6 T^{-1.296}$ & $r^{2}=0.69, n=3$ & - & $\begin{array}{l}\text { 'Development time } \\
\text { of egg sacs' }\end{array}$ & $\begin{array}{l}\text { Northern Baltic Sea, } \\
\text { Finland }\end{array}$ & Vuorinen (1982) & \\
\hline Field & $10-25$ & $D_{\mathrm{e}}=150 T^{-1.48}$ & $r^{2}=0.98, n=4$ & - & $\begin{array}{l}\text { 'Egg development } \\
\text { time' }\end{array}$ & $\begin{array}{l}\text { Gironde estuary, } \\
\text { France }\end{array}$ & $\begin{array}{l}\text { Polı \& Castel } \\
\text { (1983) }\end{array}$ & \\
\hline Field & $5.5-25$ & $D=195 T^{-165 t}$ & $r^{2}=0.99, n=5$ & - & $\begin{array}{l}\text { 'Development time } \\
\text { of eggs' }\end{array}$ & $\begin{array}{l}\text { Patuxent. River } \\
\text { estuary, USA }\end{array}$ & $\begin{array}{l}\text { Heinle \& Flemer } \\
\text { (1975) }\end{array}$ & \\
\hline Field & $0-11.8$ & $V=1640(T+10.4)^{-2.05}$ & $r^{2}=0.98, n=3$ & + & $\begin{array}{l}\text { 'Development time to } \\
\text { hatching of eggs' }\end{array}$ & $\begin{array}{l}\text { Halifax, Nova Scotia, } \\
\text { Canada }\end{array}$ & $\begin{array}{l}\text { Mclaren et al. } \\
\text { (1969) }\end{array}$ & घ \\
\hline Lab & $2-14$ & $D=18.49 T^{-0.734+}$ & $r^{2}=0.97, n=4$ & + & $\begin{array}{l}\text { 'Eggs incubation } \\
\text { time' }\end{array}$ & $\begin{array}{l}\text { Westerschelde estuary, } \\
\text { The Netherlands }\end{array}$ & $\begin{array}{l}\text { Escaravage \& } \\
\text { Soetaert (1993) }\end{array}$ & $\square$ \\
\hline Field & $2.5-25$ & $\ln D=2.722-0.2612(\ln T)^{2}$ & $r^{2}=1.00, n=6$ & + & 'Egg-duration time' & $\begin{array}{l}\text { Tjeukemeer, } \\
\text { The Netherlands }\end{array}$ & Vijverberg (1980) & $\Delta$ \\
\hline Field & $4-20$ & $D=268.8(T+3.4)^{-1.68}$ & $r^{2}=0.98, n=18$ & + & $\begin{array}{l}\text { 'Development time } \\
\text { of eggs' }\end{array}$ & Lake Ohnuma, Japan & $\begin{array}{l}\text { Ban \& Minoda } \\
\text { (1991) }\end{array}$ & 0 \\
\hline Field & $5-22$ & $\mathrm{HT}=187 \mathrm{~T}^{-1.54}$ & $r^{2}=0.97, n=6$ & + & 'Hatching time' & Present study & Present study & $\bullet$ \\
\hline $\begin{array}{l}\text { Mean all } \\
\text { data points }\end{array}$ & $0-25$ & $\mathrm{HT}=36.8 T^{-1042}$ & $r^{2}=0.87, n=37$ & + & 'Hatching time' & $\begin{array}{l}\text { All applicable } \\
\text { data compiled }\end{array}$ & Present study & \\
\hline
\end{tabular}
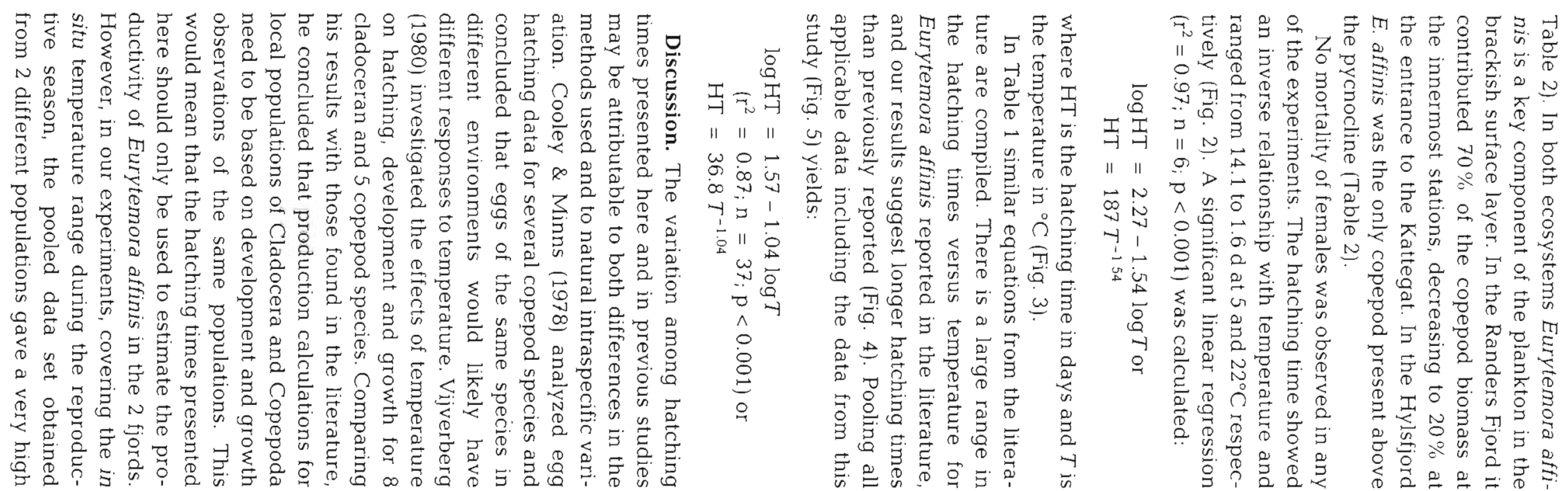


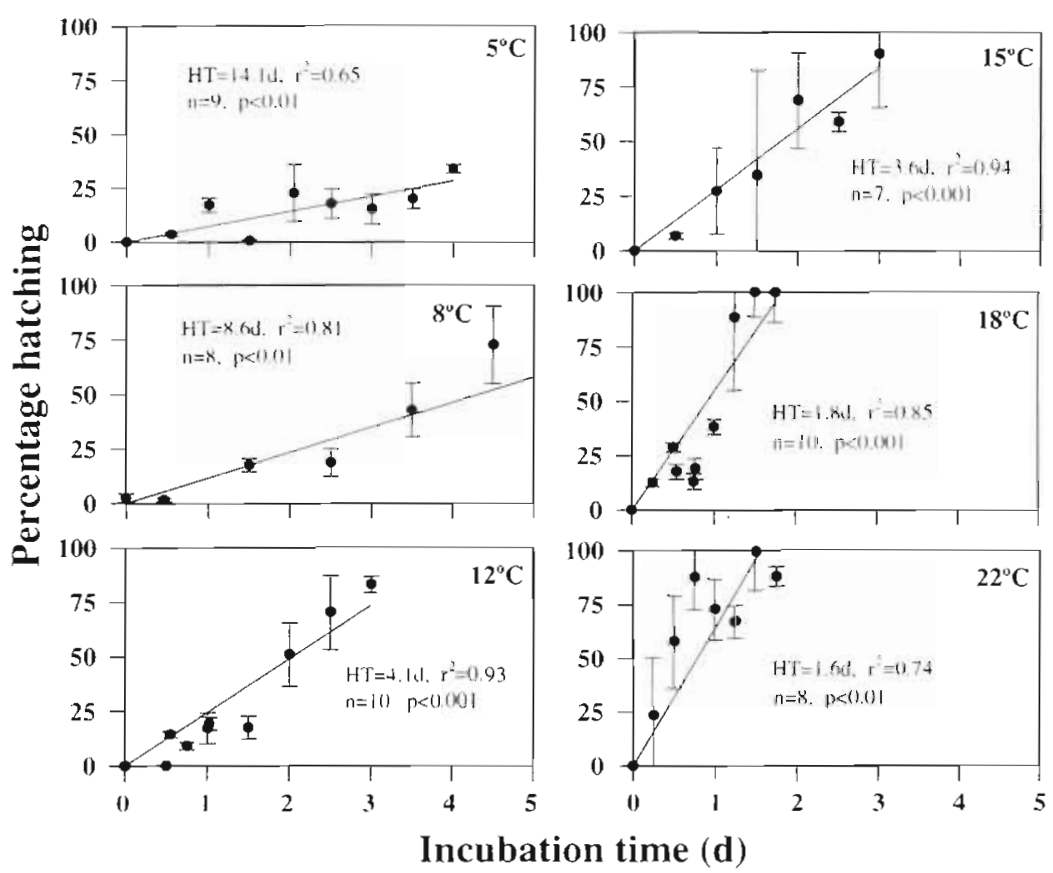

Fig. 2. Eurytemora affinis. Hatching experiments at 6 different temperatures. Hatching time (HT), $r^{2}, n$ and $p$ for the linear regression of percentage hatching vs time are indicated for each experiment. Vertical bars represent SE of the mean

regression coefficient. This suggests that variation among populations might not always be of crucial importance in the study of egg hatching times. Nevertheless we suggest that animals used in experiments should preferably be collected in the field, because there is selection for fast growth and development in cultures (Fenchel 1982, Tiselius et al. 1995). Escaravage \& Soetaert (1993) used laboratory reared copepods, which might have biased their results towards shorter hatching times.

To minimise acclimation effects the temperature in experiments should be close to that of the collection habitat or culture. In the present study the change in temperature from in situ to experimental temperature is comparable to what the copepods would experience if the pycnocline were crossed (see Table 2). Vuorinen (1987) found that reproducing Eurytemora females in the archipelago sea of southwest Finland exhibit a distinct

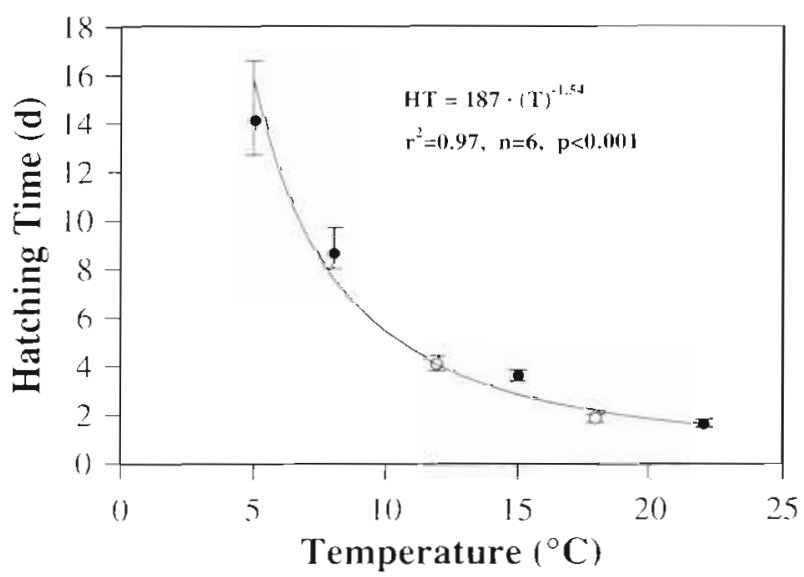

Fig. 3. Eurytemora affinis. Hatching time of eggs as a function. of temperature. (0) Hylsfjord; (•) Randers Fjord. Vertical bars represent SE of the calculated valuc diurnal migration pattern, and thereby experience changes in temperature of at least $8^{\circ} \mathrm{C}$. In the study of Ban \& Minoda (1993) some egg sacs were incubated at $15^{\circ} \mathrm{C}$ throughout the season, neglecting in situ temperature. Nevertheless they found no seasonal variations in the hatching times. This result questions the importance of acclimation in egg hatching experiments.

Hatching time can be assessed using 2 general approaches: direct observations on females with eggs or by an indirect regression method. The results of McLaren et al. (1969) and Vijverberg (1980) are based on direct observations of individual ovigerous females, while Escaravage \& Soetaert (1993) made their direct observations on paired $\left(10^{A}+10\right)$ copepods. Escaravage \& Soetaert (1993) define hatching as the moment when at least $50 \%$ of the eggs have hatched. Unless hatching is synchronised this may explain why they

Table 2. Temperature in experiments and temperature, salinity, chlorophyll a (chl a), and biomass of Eurytemora affinis at the study sites (temperature and salinity values are given for above/below the pycnocline)

\begin{tabular}{|c|c|c|c|c|c|}
\hline Locality & $\begin{array}{c}\text { Temp in experiments } \\
\left({ }^{\circ} \mathrm{C}\right)\end{array}$ & $\begin{array}{l}\text { Temp. study site } \\
\left({ }^{\circ} \mathrm{C}\right)\end{array}$ & $\begin{array}{l}\text { Salinity } \\
\left(\% \%_{0}\right)\end{array}$ & $\begin{array}{l}\operatorname{Max} \cdot \operatorname{chl} a \\
\left(\mu g l^{-1}\right)\end{array}$ & $\begin{array}{l}\text { E. affinis biomass } \\
(\% \text { of copepod biomass }\end{array}$ \\
\hline $\begin{array}{l}\text { Hylsfjord, Norway } \\
\text { Jul } 1995\end{array}$ & 12 and 18 & $16.4 / 7.1$ & $6.2 / 34.6$ & 3.61 & 100 \\
\hline $\begin{array}{l}\text { Randers Fjord, Den } \\
\text { Sep } 1995 \\
\text { May } 1996\end{array}$ & $\begin{array}{l}5 \text { and } 22 \\
8 \text { and } 15\end{array}$ & $\begin{array}{l}16.3 / 15.6 \\
10.8 / 9.4\end{array}$ & $\begin{array}{l}1.2 / 8.2 \\
1.5 / 15.3\end{array}$ & $\begin{array}{l}36.2 \\
17.0\end{array}$ & $\begin{array}{l}20-70 \\
20-70\end{array}$ \\
\hline
\end{tabular}




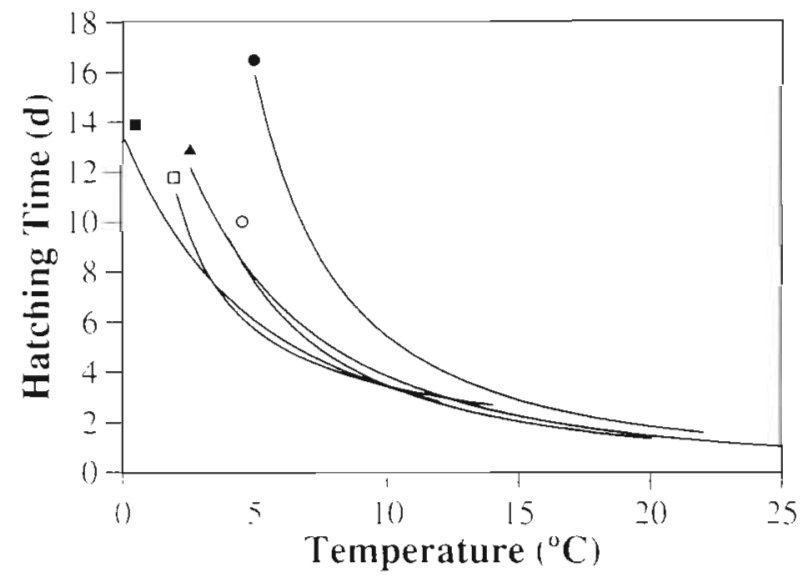

Fig. 4. Eurytemora. Hatching times of eggs as a function of temperature. Data from the present and previous studies: (a) McLaren et al. (1969); () Escaravage \& Soetaert (1993); (^) Vijverberg (1980); (0) Ban \& Minoda (1991); (•) this study

found shorter hatching times compared to this study where a $100 \%$ hatching criterion is used. In the indirect regression method the ratio or percentage of hatched eggs or egg sacs is plotted against incubation time and hatching rate is calculated as the slope of the linear regression. This method was used in the present study and by Ban \& Minoda (1991), who incubated single egg sacs dissected from anesthetized females. Their results are supported by a large number of replicates, but the mortality of egg sacs was high, probably due to the small incubation volume $(2 \mathrm{ml}$ or $0.3 \mathrm{ml})$ and because the water was not renewed. This could cause oxygen deficiency and maybe also lead to bacterial or fungal infection of eggs. The advantage of this method,

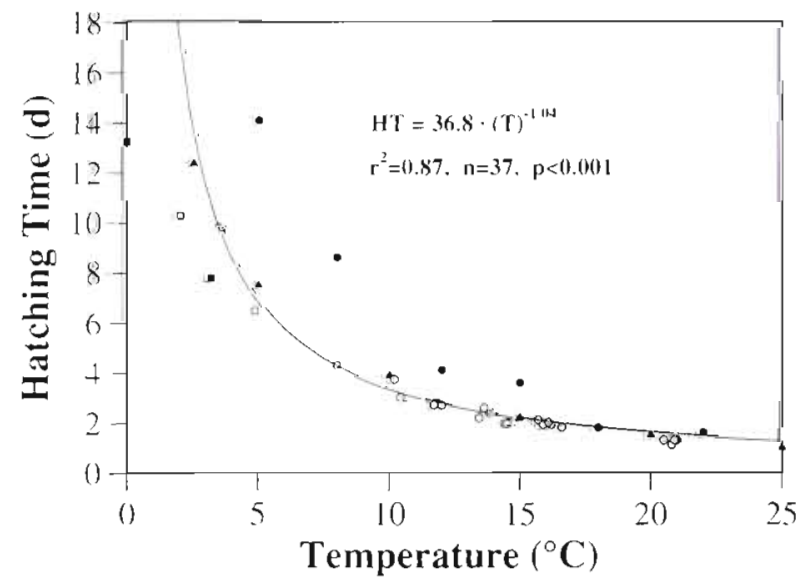

Fig. 5. Eurytemora. Hatching time of eggs as a function of temperature General relationship based on all available data points from the present and previous studies. Each datapoint represents one experiment. (-) McLaren et al. (1969); (c) Escaravage \& Soetaert (1993); (4) Vijverberg (1980); (0) Ban \& Minoda $(1991)_{i}(\bullet)$ this study though, is that it eliminates the risk of cannibalism. This phenomenon is well known from incubation experiments with several free-spawning species (Kiorboe et al. 1985b), but since eggs of Eurytemora affinis are carried by the female, cannibalism can only be on the newly hatched nauplii. Even though we expect the newly hatched nauplii to be well above the upper size limit of adult $E$. affinis prey, we have no exact information about this and cannibalism cannot be neglected as a source of error in our study. Since we calculated the hatching time on the basis of the number of nauplii, the effect of cannibalism would be longer hatching times.

The observation frequency in hatching experiments is crucial, because new egg sacs might be produced during experiments. The appearance of new eggs is dependent on the duration of the period from hatching of one brood to the extrusion into sacs of the next brood. Vijverberg (1980) found that this was temperature dependent, ranging from $1.4 \mathrm{~d}$ at $5^{\circ} \mathrm{C}$ to $0.5 \mathrm{~d}$ at $25^{\circ} \mathrm{C}$ for Eurytemora affinis. This means that the time interval between successive observations should not be more than $12 \mathrm{~h}$ and preferably shorter, maybe $6 \mathrm{~h}$. If intervals are longer, it becomes difficult to identify new egg sacs. In the present study the production of new eggs will not affect the calculated percentage of hatched eggs, since this is based on the initial number of eggs. In copepods that carry paired egg sacs, newly produced egg sacs can be identified if 1 of the 2 egg sacs is amputated prior to incubation.

It is difficult to make any conclusions about the relative importance of natural intraspecific variation to egg hatching times in Eurytemora affinis compared to the variation caused by the difference in methods used in previous studies. Therefore we have established the new general equation based on all available data. This equation can be used as a tool when site-specific egg hatching times of $E$. affinis are not available.

The egg production rate of copepod populations can be measured directly by incubation of fertilised females (Kiørboe et al. 1985a, b) or indirectly by combining data of the egg to female ratio of the population with egg hatching rates at in situ temperature (Edmonson 1965). The incubation method is well implemented in free-spawning species, while the use of this method in egg carriers is restricted to the species where the initial number of eggs in each egg sac is readily counted on females prior to incubation (e.g. Oithona plumifera; Paffenhöfer 1993). In species such as Eurytemora affinis and Oncaea mediterranea (Paffenhöer 1993) where egg sacs are very dense or the number of eggs is very high, it is impossible to count the eggs on live females, and the method cannot be implemented directly. Hansen \& Christoffersen (1995) measured the egg production in the egg-carrying freshwater species 
Cyclops strenuus and Eudiaptomus graciloides both with dense egg sacs. Prior to experiments several egg sacs were mounted on a microscope slide and the number of eggs counted. After incubation, the same procedure was followed and the egg production was calculated. This method does not take into account the possible hatching of eggs during experiments. If hatching of eggs take place, the egg production will be underestimated. To avoid this problem the nauplii produced should also be counted. An alternative is to incubate non-ovigerous females (or remove egg sacs before incubation) and continuously remove the egg sacs produced after having narcotised females with carbonated water This was done by Hansen \& Santer (1995), but the method induced high female mortality. Also the time between broods could be artificially altered (reduced) by the removal of egg sacs leading to a biased estimation of egg production.

The hatching rate method can be applied to both egg-carrying and free-spawning copepods, though the egg production in the free-spawning species could be severely underestimated, because of the very high mortality of free eggs (Liang et al 1994, Peterson \& Kimmerer 1994, Liang \& Uye 1996a, b). In eggcarrying species the egg mortality follows the mortality of females and is much lower (Ohman 1986, Liang \& Uye 1997), but here the use of the hatching rate method to estimate productivity assumes the same distribution of all adult females and no selective predation on the egg-bearing ones. This is problematic since the ratio of eggs to females measured in the field can be biased because of different diurnal migration behaviour in ovigerous and non-ovigerous females (Vuorinen 1987). Depth integrated hauls should overcome this bias.

The method applied to determine hatching time presented here can readily be implemented to other eggcarrying species. It requires only a minimum handling of copepods, samples can be fixed and counting of nauplii and eggs can take place whenever time is available. The equation presented based on all available hatching times from this study and from the literature can readily be applied to other populations of Eurytemora affinis. Finally the hatching rate method to estimate copepod productivity can also easily be applied to fixed biomass samples.

Acknowledgements. We thank the crews on RV 'Hazkon Mosby' and RV 'Gunnar Thorson' as well as Bent Boel and Verner Dam from Århus County for assistance during sampling cruises. Technical assistance in the laboratory and field was also provided by Lasse Riemann. Dan Conley, Thomas Kiorboe and Kirsten Christoffersen provided valuable comments on the manuscript. The present investigation was supported by grants from the Danish National Research Council, contract no. 11-0420-1, The Danish Environmental Research Programme, contract no. 4.19 and the EU MAST II program, contract MAS2-CT92-0031-'MEICE'

\section{LITERATURE CITED}

Ban S, Minoda T (1991) The effect of temperature on the development and hatching of diapause and subitaneous eggs in Eurytemora affinis (Copepoda: Calanoida) in Lake Ohnuma, Hokkaido, Japan. Proceedings of the Fourth International Conference on Copepoda. Bull Plankton Soc Jpn, Spec Vol

Barthel KG (1983) Food uptake and growth efficiency of Eurytemora affinis (Copepoda: Calanoida). Mar Biol 74: $269-274$

Berggreen U, Hansen B, Kiørboe T (1988) Food size spectra, ingestion and growth of the copepod Acartia tonsa during development: implications for determinations of copepod production. Mar Biol 99:341-352

Boak AC, Goulder R (1983) Bacterioplankton in the diet of the calanoid copepod Eurytemora sp. in the Humber Estuary. Mar Biol 73:139-149

Busch A, Brenning $U$ (1992) Studies on the status of Eurytemora affinis (Poppe, 1880) (Copepoda, Calanoida). Crustaceana 62(1):13-38

Castonguay M, Fitzgerald GJ (1990) The ecology of the calanoid copepod Eurytemora affinis in salt marsh tide pools. Hydrobiologia 202:125-133

Cooley JM, Minns CK (1978) Prediction of egg development times of freshwater copepods. J Fish Res Bd Can 35: $1322-1329$

Edmonson WT (1965) Reproductive rate of planktonic rotifers as related to food and temperature in nature. Ecol Monogr $35(1): 61-111$

Escaravage V, Soetaert K (1993) Estimating secondary production for the brackish Westerschelde copepod population Eurytemora affinis (Poppe) combining experimental data and field observations. Cah Biol Mar 34:201-214

Fenchel T (1982) Ecology of heterotrophic microflagellates Adaptions to heterogeneous environments. Mar Ecol Prog Ser 9:25-33

Fryd M, Haslund OH, Wohlgemuth O (1991) Development, growth and egg production of the two copepod species Centropages hamatus and Centropages typicus in the laboratory. J Plankton Res 13:683-689

Gyllenberg G (1980) Feeding of the copepod Eurytemora hirundordes (Crustacea) on different algal cultures. Ann Zool Fenn 17:181-184

Hansen AM, Santer B (1995) The influence of food resources on the development, survival and reproduction of the two cyclopoid copepods: Cyclops vicinus and Mesocyclops leuckarti. J Plankton Res 17:631-646

Hansen B. Christoffersen K (1995) Specific growth rates of heterotrophic plankton organisms in a eutrophic lake during a spring bloom. J Plankton Res 17(2):413-430

Heerkloss R (1979) Selektivität der Nahrungsaufnahme, Ingestionsrate und Faecesabgabe bei Eurytemora affinis (Poppe) (Calanoida, Copepoda). Wiss Z Univ Rostock Math-Naturwiss Reihe 28:525-529

Heinle DR, Flemer DA (1975) Carbon requirements of a population of the estuarine copepod Eurytemora affinis. Mar Biol 31:235-247

Heinle DR, Harris RP, Ustach JF, Flemer DA (1977) Detritus as food for estuarine copepods. Mar Biol 40:341-353

Irvine K, Snook D, Moss B (1995) Life histories of Neomysis integer, and its copepod prey, Eurytemora affinis, in a 
eutrophic and brackish shallow lake. Hydrobiologia 304 : $59-76$

Jeffries (1962) Salinity-space distribution of the estuarine genus Eurytemora. Int Rev Ges Hydrobiol 47:291-300

Jeppesen E, Søndergaard M, Kanstrup E, Petersen B, Eriksen RB, Hammershøj M. Mortensen $E$, Jensen JP, Have A (1994) Does the impact of nutrients on the biological structure and function of brackish and freshwater lakes differ? Hydrobiologia 275/276:15-30

Kaartvedt $S$, Svendsen $H$ (1995) Effect of freshwater discharge, intrusions of coastal water, and bathymetry on zooplankton distribution in a Norweglan fjord system. J Plankton Res 17 (3):493-511

Kiorboe T, Møhlenberg F, Hamburger K (1985a) Bioenergetics of the planktonic copepod Acartia tonsa: relation between feeding, egg production and respiration, and composition of specific dynamic action. Mar Ecol Prog Ser 26:85-97

Kiørboe T, Møhlenberg F, Riisgaard HU (1985b) In situ feeding rates on planktonic copepods: a comparison of four methods. J Exp Mar Biol Ecol 88:67-81

Liang D, Uye S (1996a) Population dynamics and production of the planktonic copepods in a eutrophic inlet of the Inland Sea of Japan. II. Acartia omorii. Mar Biol 125: 109-117

Liang $\mathrm{D}$, Uye $\mathrm{S}$ (1996b) Population dynamics and production of the planktonic copepods in a eutrophic inlet of the Inland Sea of Japan. III. Paracalanus sp. Mar Biol 127. 219-227

Liang D, Uye S (1997) Population dynamics and production of the planktonic copepods in a eutrophic inlet of the Inland Sea of Japan. IV. Pseudodiaptomus marinus, the eggcarrying calanoid. Mar Biol 128:415-421

Liang D, Uye S, Onbé T (1994) Production and loss of eggs in the calanoid copepod Centropages abdominalis Sato in Fukuyama Harbor, the Inland Sea of Japan. Bull Plankton Soc Jpn 41:131-142

McLaren IA, Corkett CJ, Zilioux EJ (1969) Temperature adap-

Editorial responsıbility: Otto Kinne (Editor),

Oldendorf/Luhe, Germany tions of copepod eggs from the arctic to the tropics. Biol Bull Mar Biol Lab Woods Hole 137:486-493

Nielsen K, Somod B, Hansen DF (1993) Eutrophication of Randers Fjord estuary, Denmark - deteriorations and improvements (1900-1991). Eur Water Pollut Control 3(4): $44-51$

Ohman MD (1986) Predator limited population growth of the copepod Pseudocalanus sp. J Plankton Res 8:673-713

Paffenhöfer GA (1993) On the ecology of marine cyclopoid copepods (Crustacea, Copepoda). J Plankton Res 15(1): $37-55$

Peterson WT, Kimmerer WJ (1994) Processes controlling recruitment of the marine calanoid copepod Temora longicornis in Long Island Sound: egg production, egg mortality, and cohort survival rates. Limnol Oceanogr 39 : $1594-1605$

Poli JN1, Castel J (1983) Cycle biologique en laboratoire d'un copépode planctonıque de l'estuaire de la Gironde: Eurytemora hirundoides (Nordquist, 1888). Vie Milieu 33(2): $79-86$

Tiselius P, Hansen B, Jonsson P, Kiørboe T, Nielsen TG, Piontkovski S, Saiz E (1995) Can we use laboratory-reared copepods for experiments? A comparison of feeding behaviour and reproduction between a field and a laboratory population of Acartia tonsa. ICES J Mar Sci 52: $369-376$

Vijverberg J (1980) Effect of temperature in laboratory studies on development and growth of Cladocera and Copepoda from Tjeukemeer, The Netherlands. Freshwat Biol 10: $317-340$

Vuorinen I (1982) The effect of temperature on the rates of development of Eurytemora hirundoides (Nordqvist) in laboratory culture. Ann Zool Fenn 19:129-134

Vuorinen I (1987) Vertical migration of Eurytemora (Crustacea, Copepoda): a compromise between the risk of predation and decreased fecundity. J Plankton Res 9: $1037-1046$

Submitted: August 11, 1997; Accepted: October 22, 1997

Proofs received from author(s): November 27, 1997 